\title{
Hastanemizde Pandemi Servisi Dışında Saptanan COVID-19 Tanısı Alan Hastalarla Temaslı Sağlık Çalışanlarının Değerlendirilmesi
}

\section{Evaluation of Healthcare Professionals in Contact with Patients Diagnosed with COVID-19 Detected Outside of the Pandemic Service in our Hospital}

\author{
Derya KORKMAZ(ID), Petek KONYA(ID), Havva TÜNAY(ID), Neşe DEMIRTÜRK(ID) \\ Afyonkarahisar Sağlık Bilimleri Üniversitesi, Sağlık Uygulama ve Araştırma Merkezi, Enfeksiyon Hastalıkları ve \\ Klinik Mikrobiyoloji Anabilim Dalı, Afyonkarahisar. \\ Afyonkarahisar Health Sciences University, Health Application and Research Center, Department of Infectious \\ Diseases and Clinical Microbiology, Afyonkarahisar, Turkey.
}

Makale Atıfı: Korkmaz D, Konya P, Tünay H, Demirtürk N. Hastanemizde pandemi servisi dışında saptanan COVID-19 tanısı alan hastalarla temaslı sağlık çalışanlarının değerlendirilmesi. Mikrobiyol Bul 2021;55(2):194-206.

\section{ÖZ}

"Severe Acute Respiratory Syndrome Coronavirus 2 (SARS-CoV-2)" etkenli "Coronavirus Disease 19 (COVID-19)" salgını pandemi olarak etkisini hala sürdürmektedir. Dünya genelinde, pandeminin başlangıcından eylül ayı başına kadar geçen sürede en az yedi bin sağlık çalışanının COVID-19 nedeni ile yaşamını kaybettiği bildirilmektedir. Ülkemizde ilk olgunun görüldüğü 11 Mart 2020 tarihinden çalışmamızı sonlandırdığımız 1 Eylül tarihine kadar yaklaşık 7428 sağlık çalışanının SARS-CoV-2 ile enfekte olduğu ve bunlardan 52'sinin yaşamını yitirdiği bilinmektedir. Bu çalışmada, hastanemizde pandemi klinikleri dışında çalışan sağlık çalışanlarından temaslı ve hasta olanların değerlendirilmesi, olası bulaş yolları ve hastalık prognozlarının irdelenmesi amaçlanmıştır. Hastanemizde 11 Mart 2020-1 Eylül 2020 tarihleri arasında, pandemi servisi dışında çalışan ve COVID-19 kesin tanısı alan sağlık çalışanları, bu kişilerle teması olan tüm hastane çalışanları ve pandemi servisi dışındaki servislerde yatarak tedavi alırken, COVID-19 tanıSı alan hastalarla teması olan sağlık çalışanları değerlendirilerek "Sağlık Bakanlığı COVID-19 Rehberi"nde tanımlanan risk skorlamasına göre düşük, orta ve yüksek riskli olarak sınıflandırılmıştır. Temaslı olarak değerlendirilen sağlık çalışanları, temas anında kişisel koruyucu ekipman (KKE) kullanımı, özellikle maske uygunluğu, temas süresi ve şekli açısından detaylı sorgulanarak bilgiler kayıt altına alınmıştır. Hastanemizde çalışma periyodu süresince COVID-19 tanısı alan 40'ı sağlık çalışanı ve 13'ü yatan hasta olmak üzere toplam 53 indeks olgu tespit edilmiştir. Bu indeks olgularla temaslı sağlık çalışanı sayısı ise 672 bulunmuştur. Çalışmada bu 40 indeks olgu ve 672 temaslı olan 712 sağlık çalışanının verileri incelenmiştir. Sağlık çalışanı olan indeks olgulardan yalnızca 3 (\%7.5)'ünde COVID-19 enfeksiyonu hastane kaynaklı olup geri kalan indeks olgularda bulaşın toplum kaynaklı olduğu tespit edilmiştir. Temaslı değerlendirmesi yapılan sağlık çalışanlarının takip sırasında \%94.2'sinde COVID-19 gelişmezken, \%5.8'inde PCR pozitif saptanmıştır. Temaslı olarak değerlendirildikten sonra, takip periyodu sırasında COVID-19 gelişen sağlık çalışanları değerlendirildiğinde olası bulaş kaynağının \%13.1'inde hasta bakımı, \%86.9'unda ise hastane 
içi sosyal ortamlarda (çay içme, sigara içme, yemek yeme, aynı odada kişisel önlem olmaksızın sohbet etme) temastan sonraki günlerde COVID-19 tanısı alan sağlık personeli ile temas şeklinde olduğu tespit edilmiştir. Temaslı olanlar maske kullanımı açısından sorgulandığında, hasta teması sırasında \%93.3'ünün maske taktığı, ancak hastane içinde diğer sağlık çalışanları ile bir arada bulunulan sosyal ortamlarda sadece \%48.9'unun maske taktığı tespit edilmiştir ( $p<0.001)$. COVID-19 pandemisi nedeniyle sağlık çalışanları benzeri görülmemiş bir mesleki hastalık ve ölüm riski ile karşı karşıyadır. Ancak sağlık çalışanlarııın uzamış pandemi süreci nedeniyle hasta bakımı sırasında titizlikle uyguladığı enfeksiyon kontrol önlemlerine, hastaların olmadığı hastane sosyal alanlarında yeterince uyum göstermediği, en fazla bulaşın da bu alanlarda olduğu gözlenmiştir. Enfeksiyon kontrol önlemleri ve KKE'lerin doğru kullanımı açısından tekrarlanan eğitimler ve hastanede her alanda bu kuralların etkin bir şekilde uygulanması için farkındalık yaratılması, gerektiğinde denetlenmesi sağlık çalışanlarının COVID-19 enfeksiyonundan korunması açısından son derece önemlidir.

\section{Anahtar kelimeler: COVID-19; sağlık çalışanı; kişisel koruyucu ekipman.}

\section{ABSTRACT}

The "Coronavirus Disease 19 (COVID-19)" caused by "Severe Acute Respiratory Syndrome Coronavirus 2 (SARS-CoV-2)" is still active all over the world as a pandemia. It is reported that at least 7000 health care workers (HCW) had lost their lives due to COVID-19 from the beginning of the pandemia till September 2020 in the world. In our country between the dates, March 11, 2020 which the first case was reported, and September 1, 2020, the date which our study has been finalized, $7428 \mathrm{HCW}$ were infected by SARS-CoV-2, and 52 of them were deceased. In this study, it was aimed to evaluate the contact and illness of healthcare workers working outside of the pandemic clinics in our hospital and to examine the possible transmission routes and disease prognoses. Healthcare workers who were working outside the pandemic service between March 11, 2020 and September 1, 2020 and who had a definite diagnosis of COVID-19 and all hospital staff who had contacted with these people, and HCW who had contact with patients diagnosed with COVID-19 while receiving inpatient treatment in services other than the pandemic service was evaluated and classified as low, medium and high risk according to the risk scoring defined in the published "Ministry of Health COVID-19 Guidelines". Healthcare workers who were evaluated as contacted were questioned in detail regarding the use of personal protective equipment (PPE) at the time of contact, especially suitability of the masks, contact time and shape and all the data were recorded. A total of 53 index cases (40 HCW and 13 inpatients diagnosed as COVID-19) were detected during the study period. The number of HCW contacted with these index cases was 672 . In our study, we examined the data of 40 index cases and 672 contacted HCW (total of $712 \mathrm{HCW}$ ). Only 3 of 40 index cases (7.5\%) had hospital-acquired COVID-19 infection, the other 37 cases were infected by community sources. COVID-19 was not detected in $94.2 \%$ of the contacted HCW during the follow-up while $5.8 \%$ of them had positive PCR test results. Considering the possible way of contamination among the contacted HCW who developed COVID-19 during the follow-up period, it was determined that $13.1 \%$ of the cases were a result of taken care of patients, $86.9 \%$ of the cases were a result of being in hospital social environments (drinking tea, smoking, eating, chatting in the same room without personal precautions) and in the days after the contact, it was in the form of contact with healthcare personnel diagnosed with COVID-19. When the contacted HCW were questioned about using proper masks at the time of contact, we determined that $93.3 \%$ of them used masks during patient caring procedures, however, only $48.9 \%$ used masks when they were in social areas $(p<0.001)$. Healthcare workers face an unprecedented risk of occupational disease and death due to the COVID-19 pandemic. However, it is also observed that prolonged pandemia period caused health workers to disregard rigorous infection control precautions in social areas of hospitals which they follow inpatient care although this has shown to be the most common way of contamination. Commonly performed in-service training and causing awareness in all areas of the hospital about following infection control precautions and PPE usage and checking the process regularly are the most important ways to prevent HCW from being affected by COVID-19.

Keywords: COVID-19; health care workers; personnel protective equipments. 


\section{Giriş}

İlk olgunun Aralık 2019'da Çin'in Wuhan kentinde bildirilmesinden bu yana tüm dünyayı büyük bir hızla saran "Severe Acute Respiratory Syndrome Coronavirus 2 (SARSCoV-2)" etkenli "Coronavirus Disease 19 (COVID-19)" salgını pandemi olarak etkisini hala sürdürmektedir. Yapılan ilk araştırmalara göre, Wuhan'da canlı hayvan pazarından kaynaklandığı bildirilen SARS-CoV-2; zarflı, pozitif sarmallı tek zincirli bir betacoronavirus'dur. Virüs esas olarak hastaların solunum sekresyonlarında yoğun olarak bulunmakta ve bu sekresyonların çevreye saçılması sonucu damlacık yolu ile duyarı kişilere bulaşmaktadır ${ }^{1}$.

COVID-19 bulaşı açısından en önemli risk grubunu hastalara bakım veren sağlık çalışanları oluşturmaktadır. Bu nedenle sağlık hizmetinin de aksamadan yürütülebilmesi için sağlık çalışanlarının korunması pandemideki en öncelikli konuların başında gelmektedir².

Dünya genelinde, pandeminin başlangııından eylül ayı başına kadar geçen sürede en az yedi bin sağlık çalışanının COVID-19 nedeni ile yaşamını kaybettiği bildirilmektedir ${ }^{3}$. Ülkemizde ilk olgunun görüldüğü 11 Mart 2020 tarihinden çalışmamızı sonlandırdığımız 1 Eylül tarihine kadar yaklaşık 7428 sağlık çalışanının SARS-CoV-2 ile enfekte olduğu ve bunlardan 52'sinin yaşamını yitirdiği bilinmektedir.

Kesin ve olası COVID-19 hastalarına bakım verilen kliniklerde, sağlık çalışanlarının korunması için uygun KKE kullanımı son derece önemlidir. Bunun dışında sağlık çalışanlarının hastane içinde yemekhaneler, toplantı alanları ve diğer sosyal alanlarda da maske ve mesafe kurallarına azami uyumu şarttır. Bu çalışmada hastanemizde, pandemi süresince, pandemi klinikleri dışında kalan hastane bölümlerinde çalışan ve COVID-19'a yakalanan sağlık çalışanlarının değerlendirilmesi, olası bulaş yolları ve hastalık prognozlarının irdelenmesi amaçlanmıştır.

\section{GEREÇ ve YÖNTEM}

Bu çalışma, Afyonkarahisar Sağlık Bilimleri Üniversitesi Klinik Araştırmalar Etik Kurulu onayı (Tarih: 11.2.2020 ve Karar No: 2020/428) ve T.C. Sağlık Bakanlığı onayı (Tarih: 16.11.2020 ve Başvuru No: 2020-07-26T164726) ile gerçekleştirildi. Bu çalışma, 11 Mart 2020-1 Eylül 2020 tarihleri arasında Afyonkarahisar Sağlık Bilimleri Üniversitesi Hastanesinde retrospektif olarak planlandı.

Çalışmaya; i) hastanemiz pandemi servisi dışında çalışan ve kesin COVID-19 tanısı alan sağlık çalışanları, ii) birinci maddede yer alan sağlık çalışanları ile teması olan tüm hastane çalışanları, iii) hastanemiz pandemi servisi dışındaki servislerde yatarak tedavi alırken COVID-19 tanısı alan hastalarla teması olan sağlık çalışanları dahil edildi. COVID-19 tanısı alan ve hastane içi temasları değerlendirilen sağlık çalışanları ile hastanede yatarken COVID-19 tanısı alan hastalar indeks olgu olarak değerlendirildi. Çalısmaya alınan hasta ve temaslıların; demografik bilgileri, klinik yakınma ve fizik muayene bulguları kaydedildi. Temaslı kişilerde bulaş riski değerlendirmesi "Sağlık Bakanlığı COVID-19 Rehberi"nde tanımlanan risk skorlamasına göre yapılarak temasılıar düşük, orta ve yüksek riskli olarak sınıflandırıldı ${ }^{4}$. Risk sınıflandırması kriterleri aşağıda özetlenmiştir: 
Yüksek riskli temas: Indeks olgu ile maske takma kurallarına uyulmadan 1 metreden daha yakın mesafede, 15 dakikadan uzun süreli teması durumu.

Orta riskli temas: Tıbbi maske takılmış COVID-19 hastasıyla maskesiz ya da N95 maske takılması gereken işlemler sırasında cerrahi maske takarak yoğun temas varlığı ya da kurallara uygun maske kullanımı, ancak göz koruyucu kullanmama durumu.

Düşük riskli temas: Tıbbi maske takılmış COVID-19 hastasıyla maske takma kurallarına uygun ancak eldiven, önlük ve göz koruyucu kullanılmadan yoğun temas durumu ya da tıbbi maske takılmamış COVID-19 hastası ile maske kullanım kurallarına uygun ancak eldiven ve önlük kullanılmadan yoğun temas durumu.

COVID-19 tanısı alan sağlık çalışanlarından asemptomatik ve hafif semptomatik olanlar tedavi verilerek ayaktan; orta ve ağır semptomatik olanlar yatırılarak takibe alındı. Klinik gidiş ve prognozları değerlendirildi.

Temaslı sağlık çalışanları risk skoru belirlendikten sonra aşağıdaki şekilde takibe alındı:

a) Yüksek riskli teması olan sağlık çalışanları; aktif semptom takibi yapması söylenerek evde izole edilip izlendi; semptom gelişirse semptom günü, gelişmez ise 7 . günde polimeraz zincir reaksiyonu (PCR) testi yapıldı. Testi pozitif olanlar COVID-19 tanısı konularak takibe alındı, negatif olanlar 14 güne kadar semptom takibi yapmak üzere işe başlatıldı (Şekil 1).

b) Orta riskli teması olan sağlık çalışanları; maske ile çalışıp aktif semptom takibi ile izlendi. Semptom gelişirse semptom günü, gelişmez ise 7. günde PCR testi yapıldı. Testi pozitif olanlar COVID-19 tanısı konularak takibe alındı; negatif olanlar 14 güne kadar semptom takibi yapmak üzere işe başlatıldı.

c) Düşük riskli teması olan sağlık çalışanlarında; maske ile çalışıp toplam süre temas sonrası 14 güne tamamlanacak şekilde aktif semptom takibi yapıldı, semptom gelişmeyenlerde takip sonlandırılırken, semptom gelişenlerde semptom gününde PCR testi yapıldı.

Temaslı olarak değerlendirilen sağlık çalışanları, temas anında KKE uygunluğu, temas süresi ve şekli açısından detaylı sorgulanarak bilgiler kayıt altına alındı. KKE içinde maske kullanımı ayrıca sorgulanarak temaslı sağlık çalışanlarının maske kullanımına uyumu değerlendirildi.

\section{İstatistiksel Analiz}

İstatistiksel analiz için IBM SPSS Statistic 22 versiyon paket programı kullanıldı. Kategorik veriler için frekans ve yüzdelikler, nicel veriler için ortalama ve standart sapma verildi. Kategorik değişkenlerin arasındaki farklılıkların incelenmesinde ki-kare testinden yararlanıldı.

\section{BULGULAR}

Afyonkarahisar Sağlık Bilimleri Üniversitesi Hastanesi; 650 yataklı bir hastane olup hastanemizde 351 hekim, 462 hemşire, 122 yardımcı sağlık personeli ve 799 diğer destek 


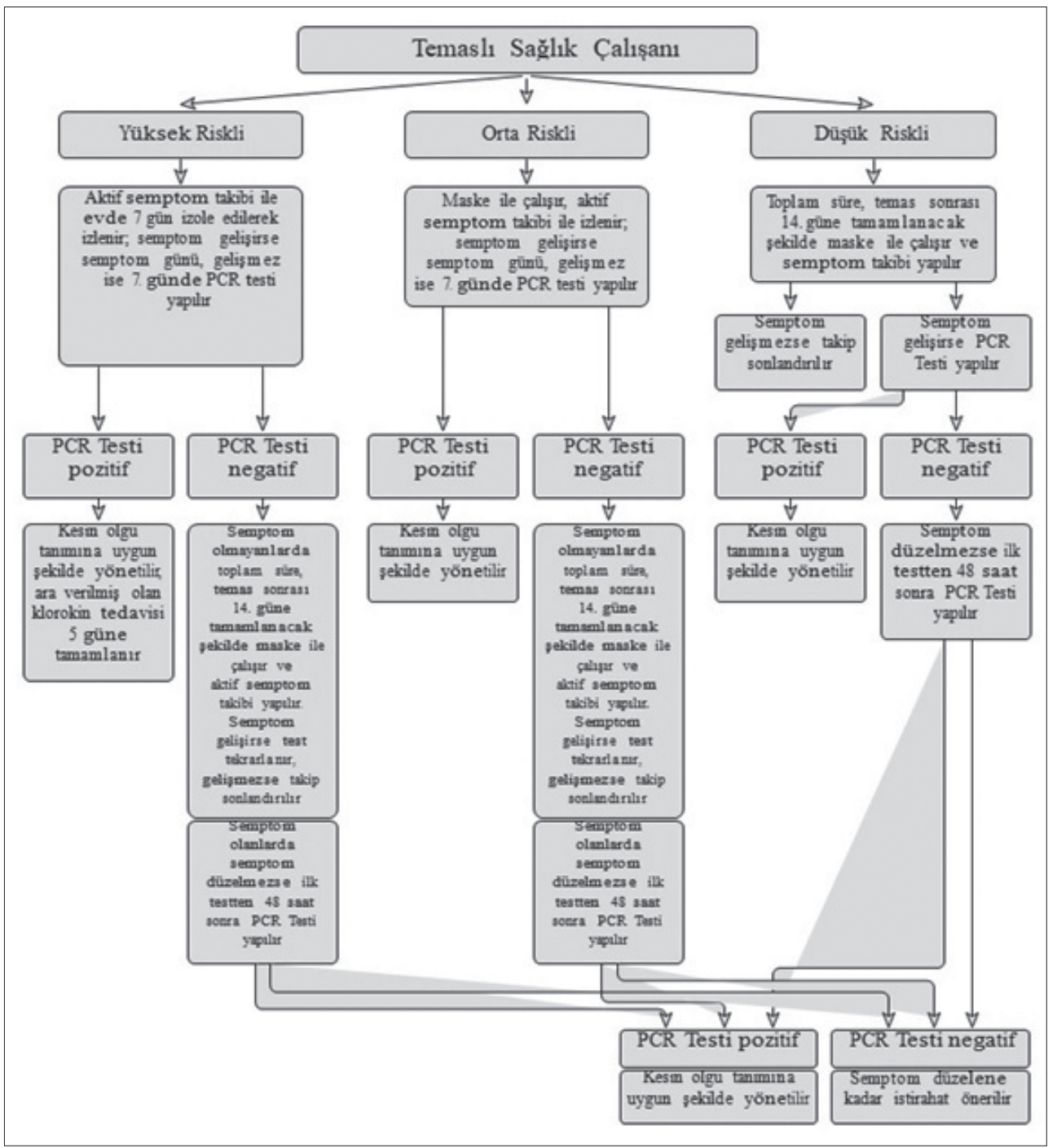

Şekil 1. Teması sağık çalışanı algoritması.

personeli (sekreter, güvenlik, temizlik personeli vb.) olmak üzere toplam 1734 sağlık çalışanı bulunmaktadır.

Hastanemizde, çalışma periyodu süresince COVID-19 tanısı alan 40’ı sağlık çalışanı ve 13'ü yatan hasta olmak üzere toplam 53 indeks olgu tespit edilmiştir. Bu indeks olgularla temaslı sağlık çalışanı sayısı ise 672 bulunmuştur. Çalışmamızda bu 40 indeks olgu ve 672 temaslı olan 712 sağlık çalışanının verileri incelenmiştir.

Çalışma periyodumuz süresince, hastane personelinin temaslı olduğu 53 indeks olgu tespit edilmiş ve indeks olguların 40'ı hastane sağlık çalışanı olarak bulunmuştur. 
İndeks olgu olarak değerlendirilen COVID-19 tanılı sağlık çalışanlarının 18 (\%45)'i erkek, 22'si kadın olup yaş ortalaması $32.5 \pm 7.7$ olarak hesaplanmıştır. Sağlık çalışanı olan indeks olgulardan yalnızca üçünde (\%7.5) COVID-19 enfeksiyonu hastane kaynaklı olup geri kalan indeks olgularda bulaş toplum kaynaklı bulunmuştur. Olguların 31'i ayakta, 9 (\%17)'u yatarak tedavi edilmiş; yatan hastalardan sadece biri yoğun bakımda izlenmiş, yatan hastalardan 2 (\%5)'sine immün plazma tedavisi verilmiştir. İndeks olguların dokuzunda tomografik incelemede akciğerlerde viral pnömoni ile uyumlu bulgular mevcutken, 19'unda atipik bulgular saptanmış, 12'sinde ise akciğer tomografilerinde pnömoni bulgusu izlenmemiştir. Olguların hepsi şifa ile sonuçlanmış olup özellikleri Tablo I'de gösterilmiştir.

Temaslı olarak değerlendirilen 672 sağlık çalışanından 264 (\%39.3)'ü erkek, 408 (\%60.7)'i kadın olup ortalama yaş $33.1 \pm 8.2$ olarak hesaplanmıştır. Görev dağılımı değerlendirildiğinde çalışanların \%18.9'u hekim, \%34.7'si hemşire, \%32.6'sı diğer yardımcı sağlık personeli (laboratuvar teknisyeni, hasta bakım elemanı, temizlik personeli), \%7.4'ü

\begin{tabular}{|c|c|c|}
\hline & $\mathbf{n}$ & $\%$ \\
\hline \multicolumn{3}{|l|}{ Cinsiyet } \\
\hline Erkek & 18 & 45.0 \\
\hline Kadın & 22 & 55.0 \\
\hline \multicolumn{3}{|l|}{ Görevi } \\
\hline Hekim & 9 & 22.5 \\
\hline Hemşire & 15 & 37.5 \\
\hline Sekreter & 3 & 7.5 \\
\hline Öğrenci & 4 & 10 \\
\hline Diğer & 9 & 22.5 \\
\hline \multicolumn{3}{|l|}{ Temaslı olduğu bulaş kaynağı } \\
\hline Hasta & 2 & 5.0 \\
\hline Hastanede sosyal ortam & 1 & 2.5 \\
\hline Hastane dışı sosyal ortam & 37 & 92.5 \\
\hline \multicolumn{3}{|l|}{ Tedavi verilen yer } \\
\hline Hastane & 9 & 22.5 \\
\hline $\mathrm{Ev}$ & 31 & 77.5 \\
\hline \multicolumn{3}{|l|}{ Tedavide kullanılan ajanlar } \\
\hline Hidroksiklorokin & 26 & 65.0 \\
\hline Favipravir & 9 & 22.5 \\
\hline Hidroksiklorokin + Favipravir & 5 & 12.5 \\
\hline İmmün Plazma & 2 & 5.0 \\
\hline Antibiyotik & 5 & 12.5 \\
\hline \multicolumn{3}{|l|}{ Akciğer Tomografi Bulguları } \\
\hline Yok & 12 & 30.0 \\
\hline Tipik & 9 & 22.5 \\
\hline Atipik & 19 & 47.5 \\
\hline
\end{tabular}


tıp fakültesi öğrencisi, \%6.4'ü tıbbi sekreter olarak belirlenmiştir (Tablo II). Bunlardan 206'sı düşük riskli, 261'i orta riskli, 205'i yüksek riskli olarak değerlendirilmiştir (Tablo III).

Temaslı değerlendirmesi yapılan sağlık çalışanlarının, takip sırasında \%94.2'sinde COVID-19 gelişmezken, \%5.8'inde PCR pozitif saptanmış ve bu hastaların iki tanesi indeks olgu olup diğer personeli de enfekte etmiştir. Temaslı olarak değerlendirildikten sonra, takip

\begin{tabular}{lcc}
\hline Tablo Il. Teması Sağık Çalışanlarının Özellikleri & & \\
\hline & $\mathbf{n}$ & $\%$ \\
\hline Cinsiyet & 264 & 39.3 \\
Erkek & 408 & 60.7 \\
Kadın & & \\
Görevi & 127 & 18.9 \\
Hekim & 233 & 34.7 \\
Hemşire & 43 & 6.4 \\
Sekreter & 50 & 7.4 \\
Öğrenci & 219 & 32.6 \\
Diğer & & \\
Temaslı olduğu bulaş kaynağı & 88 & 13.1 \\
Hasta & 584 & 86.9 \\
Hastane içi sosyal ortam & & \\
RT-PCR & 39 & 5.8 \\
Pozitif & 633 & 94.2 \\
Negatif & & \\
\hline
\end{tabular}

RT-PCR: Revers transkriptaz polimeraz zincir reaksiyonu.

\begin{tabular}{|c|c|c|}
\hline & $\mathbf{n}$ & $\%$ \\
\hline \multicolumn{3}{|l|}{ Risk Durumu } \\
\hline Yüksek & 205 & 30.5 \\
\hline Orta & 261 & 38.8 \\
\hline Düşük & 206 & 30.7 \\
\hline \multicolumn{3}{|l|}{ Maske } \\
\hline Maskeli & 369 & 54.9 \\
\hline Maskesiz & 271 & 40.3 \\
\hline Emin değil & 32 & 4.8 \\
\hline \multicolumn{3}{|l|}{ Mesafe } \\
\hline 1 m'den yakın & 332 & 49.4 \\
\hline 1 m'den uzak & 340 & 50.6 \\
\hline \multicolumn{3}{|l|}{ Süre } \\
\hline $15 \mathrm{dk}^{\prime}$ dan fazla & 226 & 33.6 \\
\hline $15 \mathrm{dk}^{\prime} \mathrm{dan} a z$ & 446 & 66.4 \\
\hline
\end{tabular}


periyodu sırasında COVID-19 gelişen sağlık çalışanları değerlendirildiğinde olası bulaş kaynağının \%13.1'inde hasta bakımı, \%86.9'unda ise hastane içi sosyal ortamlarda (çay içme, sigara içme, yemek yeme, aynı odada kişisel önlem olmaksızın sohbet etme) temastan sonraki günlerde COVID-19 tanısı alan sağlık personeli ile temas şeklinde olduğu tespit edilmiştir. Temaslı olarak değerlendirilen kişi sayısı en fazla ağustos ayında saptanmıştır (Şekil 2).

Temaslı değerlendirmesi yapılan sağlık çalışanları, maske kullanımı açısından sorgulandığında, hasta teması sırasında \%93.3'ünün maske taktığı ancak hastane içinde diğer sağlık çalışanları ile bir arada bulunulan sosyal ortamlarda sadece \%48.9'unun maske taktığı tespit edilmiştir $(p<0.001)$. Maske uyumu değerlendirildiğinde mesleğe $(p=0.247)$ ve cinsiyete göre $(p=0.518)$ farklılık göstermediği saptanmıştır. Temaslı sağlık çalışanlarının maske kullanımına göre hasta olma oranları değerlendirildiğinde, temas anında maskeli olanlarda \%2.7 oranında, maskesiz olanlarda ise \%10.2 oranında temas sonrası COVID-19 geliştiği saptanmıştır $(p<0.001)$. Ayrıca hasta olanların \%73.2'si 1 m'den yakın temas tariflemiştir. Değerlendirilen temaslıların, temas sırasındaki maske kullanım durumları Tablo IV'te gösterilmiştir. Yüksek riskli olanların $\% 4.9^{\prime} \mathrm{u}$, orta riskli olanların

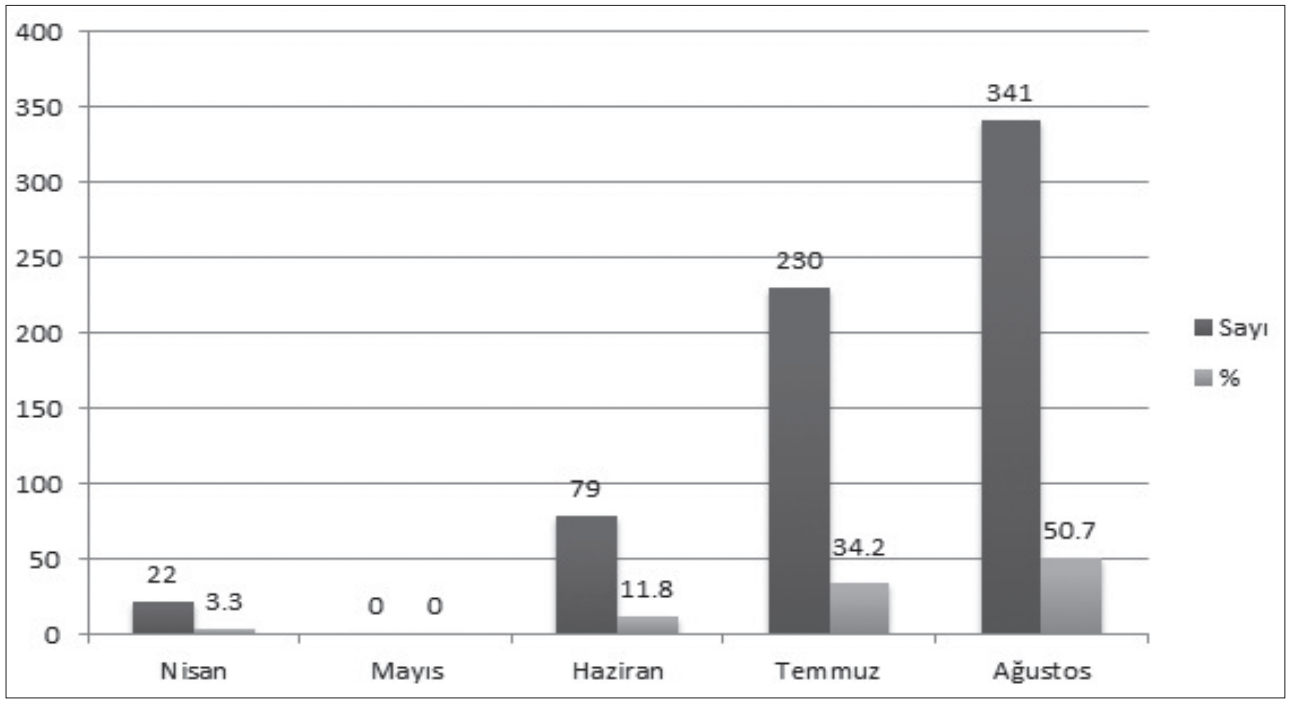

Şekil 2. Temaslı sağlık çalışanı sayısının aylara göre dağılımı.

\begin{tabular}{lcc}
\multicolumn{3}{l}{ Tablo IV. Temaslı Olan Sağlık Çalışanlarının Temas Sırasındaki Maske Durumları } \\
\hline Maske durumu & Sayı $(\mathbf{n = 6 7 2})$ & Yüzde $(\% 100)$ \\
\hline Her ikisi de maskeli & 191 & 28.4 \\
Her ikisi de maskesiz & 261 & 38.8 \\
Çalışan maskeli, karşı taraf maskesiz & 178 & 26.5 \\
Çalışan maskesiz, karşı taraf maskeli & 10 & 1.5 \\
Emin değil & 32 & 4.8
\end{tabular}


\%6.9'u, düşük riskli olanların ise \%5.3'ü takiplerinde COVID-19 tanısı almıştır. Takiplerinde COVID-19 tanısı alan temaslıların \%28.2'sinin düşük, \%46.2'sinin orta, \%25.6'sının yüksek risk grubunda $(p=615)$ olduğu belirlenmiştir .

Yüksek riskli teması olan hastalara verilen izolasyonlar ve pozitif saptanan çalışanların evde ve hastanede izolasyon süreleri değerlendirildiğinde temaslar nedeniyle toplamda 1966 gün iş gücü kaybı oluştuğu saptanmıştır.

\section{TARTIŞMA}

Mevcut kanıtlar COVID-19'un bulaş yolunun yakın temas ve damlacık yoluyla olduğunu göstermektedir ${ }^{5}$. Bu hastalığı edinme riski en yüksek olanlar, COVID-19 tanılı hastayla teması olanlar veya hasta bakımını yapanlardır ${ }^{6}$. Bu nedenle COVID-19 hastalarına bakım veren sağlık çalışanları, bu enfeksiyon açısından yüksek riskli kabul edilmekte ve sağlık çaışanlarının korunması en önemli önceliklerden biri olarak değerlendirilmektedir ${ }^{4,6}$. Sağlık çalışanlarının korunması, pandemi nedeni ile aşırı yoğunluk yaşayan sağlık sistemlerinde hasta bakımının sürdürülmesinde hayati öneme sahiptir. Ayrıca sağlık çalışanının alacağı koruyucu önlemler, sağlık çalışanından hastanedeki hastalara virüs yayılımını engellemek için de önemlidir ${ }^{7,8}$.

Pandeminin ilk aylarında sağlık çalışanlarında COVID-19'un değerlendirildiği Çin'de yapılan bir çalışmada, ocak-mart arasında 23 sağlık çalışanının COVID-19 nedeniyle hayatını kaybettiği, ancak mart-nisan arasında 42600 sağlık çalışanından hiçbirinin enfekte olmadığı bildirilmiş; yeterli koruyucu önlem alınması ve bu önlemlerin uygulanmasının sıkı denetimi ile sağlık çalışanlarının SARS-CoV-2 ile enfekte olmasının önlenebileceği vurgulanmıştır?

Hastanelerde güvenli KKE kullanımı ve pandemi olgularının yayılımını engellemek için yapılması gerekenlerle ilgili hizmet içi eğitimler ve bu eğitimlerde anlatılan önlemlere, uygulamada ne kadar dikkat edildiğinin denetlenmesi büyük önem taşımaktadır ${ }^{10}$. Türkiye'de 2005 yılında yayımlanan "Yataklı Tedavi Kurumları Enfeksiyon Kontrol Yönetmeliği" gereğince, tüm hastane çalışanlarına her yıl periyodik olarak, Enfeksiyon Kontrol Komiteleri (EKK) tarafından izolasyon önlemlerini de içeren hastane enfeksiyonlarından korunma ile ilgili eğitimler verilmektedir ${ }^{11}$. COVID-19 pandemi olgularının ülkemizde de görülmeye başlandığı mart ayından bu yana ülkemizdeki tüm hastanelerde, hastane pandemi eylem planları oluşturulmuş olup, bu planlar içinde hastane enfeksiyonlarından korunma ile ilgili eğitimler daha da arttırılmıştır. Literatürde, sağlık çalışanlarının COVID$19^{\prime}$ dan korunmasında bilgi düzeylerinin tekrarlayan eğitimlerle arttırılmasının önemli olduğu bildirilmektedir ${ }^{8}$. Hastanemizde de, sağlık çalışanlarının konu ile ilgili bilgilendirilmesine büyük önem verilmiş, COVID-19 pandemi ilan edilir edilmez SARS-CoV-2'nin bulaş yolları ve COVID-19 ile ilgili bilgilendirmeler mevcut EKK eğitim programlarımıza eklenmiştir. COVID-19 bulaşı ve korunma önlemlerini içeren bu eğitimler, hastane koşulları çerçevesinde zaman zaman yüz yüze, zaman zaman da yazılı dokümanlar ve videolar şeklinde periyodik olarak sürdürülmektedir. 
Dünya genelinde en az yedi bin sağlık çalışanının SARS-CoV-2 enfeksiyonu nedeniyle hayatını kaybettiği bildirilmiştir ${ }^{3}$. Bir meta analiz çalışması, değerlendirilen COVID-19 hastaları arasında sağlık çalışanlarının genel oranının yaklaşık \%10 olduğunu göstermiş$\mathrm{tir}^{12}$. Çin'in Wuhan kentinden erken bir olgu serisinde, SARS-CoV-2 enfeksiyonlu hastaların \%29'u sağlık çalışanı olarak tespit edilmiş olup enfeksiyonu hastanede kazandıkları varsayılmıştır $^{13,14}$. Zonguldak'ta yapılan bir çalışmada 20 Mart-20 Mayıs 2020 tarihleri arasında COVID-19 polikliniğine başvuran 703 sağlık çalışanından 50'sinde gerçek zamanlı revers transkriptaz PCR (rRT-PCR) yöntemi ile çalışılan üst solunum yolu örnekleri SARS-CoV-2 açısından pozitif saptanmış, COVID-19 gelişen sağlık çalışanlarından 14'ü asemptomatik, 36'sı semptomatik ve 7'si yatan hasta olarak tedavi edilmiş, bu hastalarda ölüm veya yoğun bakım ünitesi gereksinimi olmamıştır. Bu çalışmadaki olguların 31'i ayaktan, 9 (\%17)'u yatarak tedavi edilmiş, yatan hastalardan sadece biri yoğun bakımda izlenmiştir; hastalığın ölümle sonuçlanmamış olması sevindiricidir ${ }^{15}$.

Hastanemizde pandemi servisi dışında olası olgu olarak değerlendirilip COVID-19 tanısı alan hastalarla temas eden sağlık çalışanları "Sağlık Bakanlığı COVID-19 Rehberi" doğrultusunda temas sırasında yaptıkları işlemlere ve aldıkları önlemlere göre kategorize edilerek değerlendirilmiştir (Şekil 1). Çalışma periyodumuz süresince, pandemi servisi dışında çalışan ve saptadığımız 53 indeks olgu ile temaslı 672 sağlık çalışanı değerlendirilmiştir. Temaslı personelin \%30.5'inde yüksek risk tespit edilmiştir. Tüm hastane personeli COVID-19'dan korunma önlemleri konusunda eğitim almış olmasına karşın indeks olgu ile temasında yüksek risk saptanan kişilerin oranının bu kadar yüksek olması, eğitimin pandemiden korunmak için tek başına yetersiz olduğu gerçeğini ortaya çıkarmaktadır. Bu nedenle eğitimlerde anlatılan korunma önlemlerine uygulamada ne kadar uyulduğunun denetlenmesi, uyumsuzluk saptandığında da sebeplerinin tespit edilmesi ve uyumun arttırılması hastane içinde pandemi kontrolü için çok önemlidir.

Temaslı değerlendirmesi yapılan sağlık çalışanlarının \%5.8'inde temas sonrası COVID-19 gelişmiştir. Bu kişilerin \%86.9'unda temas hastane içi sosyal ortamlarda olmuştur. Bu sonuç, hastane çalışanlarının sosyal ortamlarda hastalık bulaşı olmayacağı, çalışma arkadaşlarının SARS-CoV-2 taşımayacağı düşüncesinde olduklarını düşündürebilir. Hasta bakımı sırasında KKE kullanımına uyumun daha fazla olması hastalardan SARS-CoV-2 bulaşını engelleyebilir. Nitekim çalışmamızda, sağlık çalışanlarının maske kullanım kurallarına hasta bakımı sırasında maksimum uyum gösterirken hastane sosyal alanlarında uymadığı görülmüştür $(p=0.001)$. Yoğun hasta bakımı ve yorgunluk, sağlık çalışanlarının hastane içi sosyal ortamlarında ve dinlenme alanlarında KKE kullanımına dikkat etmemesine neden olabilir. Tüm bu nedenlerle hastane pandemi eğitimlerinde, hastane içi sosyal alanlarda da COVID-19'dan korunma önlemlerine en az hasta bakımı sırasında olduğu kadar uyulması gerekliliğinin özellikle vurgulanması önemli bir zorunluluktur. Ayrıca, sağlık çalışanları arasında pandemi yayılımını engellemek için hastane sosyal alanlarında korunma önlemlerine uyum düzenli olarak denetlenmelidir.

Sağlık çalışanlarının sosyal alanlarda yetersiz KKE kullanımının bir nedeni de yeterli malzeme temin edilememesi olabilir. Zira pandemi nedeni ile artan KKE ihtiyacı ve tüm 
dünyada bu ihtiyacı karşılayacak yeterli üretimin olmaması, hastanelerde KKE sıkıntısı yaşanmasına neden olmaktadır ${ }^{16}$. Yeterli KKE temin edilememesi, sağlık çalışanlarına, hastaların olmadığı alanlarda, hastane yönetimi tarafından KKE sağlanamamasına neden olabilir. Bu alanlarda sağlık çalışanlarının kendilerini hasta bakılan alanlara göre daha güvende hissetmesi, çalışma arkadaşları ile temas sırasında KKE kullanımını önemsememelerinin diğer bir nedeni olabilir. Hastanemizde bu süreçte yeterli KKE bulunmasına rağmen, COVID-19 gelişen hastane içi temaslı sağlık çalışanlarının çoğunun, hastalığı sosyal alanlarda diğer çalışma arkadaşları ile temas sonrasında kazanmış olması bu görüşlerimizle uyumludur. Bu nedenle hastanenin her alanında, yeterli KKE temini ve bunların etkin kullanımı sağlık çalışanlarının korunması açısından çok önemlidir.

Hastanelerde COVID-19'dan korunmak için KKE'lerin doğru kullanımı özellikle önem taşımaktadır. KKE içinde, COVID-19'dan korunmak için önemi en büyük olan maskedir ${ }^{17}$. Çalışmamızda temaslı değerlendirmesi yaptığımız sağlık çalışanlarının, hasta ile temas anında, sosyal alanlarda diğer sağlık personeli ile bir arada bulunduğu zamanlara göre doğru maske kullanım oranının anlamlı düzeyde yüksek olduğu tespit edilmiştir $(p=0.001)$. Oysaki pandemiden korunmanın en önemli yolu toplu alanların tamamında maske kullanımıdır ${ }^{18}$. Nitekim COVID-19 saptanan sağlık çalışanlarında, temas anında doğru maske kullananların oranı kullanmayanlara göre anlamlı düzeyde düşüktür. Hastanelerde hastane personelinin, hastalarla olduğu kadar diğer sağlık çalışanları ile temasta da maske kullanımı, hastane içi pandemi yayılımının önlenmesinde son derece önemlidir. Hasta olan çalışanların önemli bir kısmı 1 m'den yakın mesafeli temas tariflemektedir. Dolayısıyla personele verilen eğitimlerde, hastane içi sosyal ortamlarda da KKE kullanımı ve sosyal mesafe kurallarına uyumun önemi özellikle vurgulanmalıdır. Bu çalışmada, değerlendirilen temaslı sağlık çalışanlarından hasta muayenesi esnasında doğru maske kullananların oranının, hastane içi sosyal ortamlarda diğer sağlık çalışanları ile bir arada iken doğru maske kullananlardan anlamlı düzeyde yüksek olduğu bulunmuştur. Hastane içinde pandemi yayılımını engellemek için sadece hasta teması değil, toplu olarak bulunan tüm alanlarda maske kullanımı ve sosyal mesafe kurallarına uyum son derece önemlidir. Bunu doğrular şekilde bizim çalışmamızda da COVID-19 gelişen temaslı sağlık çalışanlarının sadece \%13.1'inde temas, hasta bakımı sırasında gelişirken geri kalanında hastane içi sosyal alanlarda olmuştur. Bu temasların bir kısmının da maskesiz açık alanlarda sosyal mesafe kuralına uyulmadan sigara, çay, kahve içme şeklinde olduğu saptanmıştır. Tüm bu veriler değerlendirildiğinde, hastanede verilen pandemiden korunma eğitimlerinin uygulamadaki denetlemelerinin, hastane içi sosyal alanlarda da yapılması gerektiği görülmektedir. Çalışma periyodumuz boyunca pandemi servisimizde hiçbir sağlık çalışanında COVID-19 enfeksiyonu gelişmemiş olması görüşlerimizi desteklemektedir.

Çalışmamızda elde edilen sonuçlar; hastanelerde yemekhane, doktor odaları, hemşire ve personel dinlenme odalarında, ortamda hasta bulunmaması nedeniyle sağlık personelinin yalancı bir güven hissine kapıldığını, bu duruma aylardır süren pandeminin getirdiği yorgunluk da eklendiğinde korunma önlemlerinin askıya alınabildiğini göstermektedir. Bu tehlikeli durum, sağlık çalışanında COVID-19 gelişminin engellenmesi için tekrarlanan eğitimler, denetimler ve motivasyon arttırıcı önlemlerle engellenmelidir. 
Sonuç olarak, COVID-19 pandemisi nedeniyle sağlık çalışanları benzeri görülmemiş bir mesleki hastalık ve ölüm riski ile karşı karşıyadır. KKE eksikliği ve/veya uygunsuz kullanımı, enfekte hastalara uzun süre maruz kalma, uzamış bedensel ve psikolojik yorgunluk, artmış iş yükü, zayıf enfeksiyon kontrolü; sağlık çalışanlarını nozokomiyal COVID-19 enfeksiyonu açısından risk altına sokmaktadır. Ancak sağlık çalışanlarının uzamış pandemi süreci nedeniyle hasta bakımı sırasında titizlikle uyguladığı enfeksiyon kontrol önlemlerine hastaların olmadığı hastane sosyal alanlarında yeterince uyum gösterilmediği, en fazla bulaşın da bu alanlarda olduğu gözlenmiştir. Enfeksiyon kontrol önlemleri ve KKE'lerin doğru kullanımı açısından tekrarlanan eğitimler ve hastanede her alanda bu kuralların etkin bir şekilde uygulanması için farkındalık yaratılması, gerektiğinde denetlenmesi sağlık çalışanlarının COVID-19 enfeksiyonundan korunması açısından son derece önemlidir.

\section{ETIK KURUL ONAYI}

Bu çalışma, Afyonkarahisar Sağlık Bilimleri Üniversitesi Klinik Araştırmalar Etik Kurulu onayı (Tarih: 11.2.2020 ve Karar No: 2020/428) ve T.C. Sağlık Bakanlığı onayı (Tarih: 16.11.2020 ve Başvuru No: 2020-07-26T164726) ile gerçekleştirildi.

\section{ÇIKAR ÇATIŞMASI}

Yazarlar bu makale ile ilgili herhangi bir çıkar çatışması bildirmemişlerdir.

\section{KAYNAKLAR}

1. Guan W, Ni Z, Hu Y, Liang W, Ou C, He J, et al. Clinical characteristics of coronavirus disease 2019 in China. N Engl J Med 2020; 382(18): 1708-20.

2. Centers for Disease Control and Prevention. Interim U.S. guidance for risk assessment and public health management of health care personnel with potential exposure in a health care setting to patients with 2019 novel coronavirus (2019-nCoV). Available from: www.cdc.gov/coronavirus/2019-ncov/hcp/guidance-riskassesment-hcp.html. Accessed date: 1 November 2020.

3. Amnesty International. Exposed, silenced, attacked: failures to protect health and essential workers during the COVID-19 pandemic. 2020; 61. Available from: https://www.amnesty.org/download/Documents/ POL4025722020ENGLISH.PDF. (Accessed date: 28 October 2020).

4. T.C. Sağlık Bakanlığı Halk Sağlığı Genel Müdürlüğü. COVID-19 (SARS-CoV-2 Enfeksiyonu) Temaslı Takibi, Salgın Yönetimi, Evde Hasta İzlemi ve Filyasyon. Available from: https://covid19.saglik.gov.tr/ Eklenti/38673/0/covid-19rehberitemaslitakibievdehastaizlemivefilyasyonpdf.pdf. (Accessed Date: 15 October 2020).

5. Chang D, Xu H, Rebaza A, Sharma L, Dela Cruz CS. Protecting health-care workers from subclinical coronavirus infection. Lancet Respir Med 2020; 8(3): e13.

6. Chen W, Huang Y. To protect health care workers better, to save more lives with COVID-19. Anesth Analg 2020; 131(1): 97-101.

7. Tan Z, Wen D, Khoo S, Zeng LA, Tien JC, Kwang A, et al. Protecting health care workers in the front line : Innovation in COVID-19 pandemic. J Glob Health 2020; 10(1): 1-4.

8. Wang J, Zhou M, Liu F. Reasons for healthcare workers becoming infected with novel coronavirus disease 2019 (COVID-19) in China. J Hosp Infect 2020; 105(1): 100-1.

9. Zhan M, Qin Y, Xue X, Zhu S. Death from COVID-19 of 23 health care workers in China. N Engl J Med 2020; 382(23): 2267-8. 
10. Ñamendys-Silva SA. Health care workers with COVID-19 in Mexico. Eur Respir J 2020; 56: 2002885.

11. Yataklı Tedavi Kurumları Enfeksiyon Kontrol Yönetmeliği. Resmi Gazete: 11 Ağustos 2005 - 25903. Available from: https://www.ttb.org.tr/mevzuat/index.php?option=com_content\&view=article\&id=333:yatakli-tedavkurumlarienfeksiyon-kontrol-yetmel\&catid=2:ymelik\&Itemid=33. Accessed date: 18 October 2020.

12. Sahu AK, Amrithanand VT, Mathew R, Aggarwal P, Nayer J, Bhoi S. COVID-19 in health care workers - A systematic review and meta-analysis. Am J Emerg Med 2020; 38(9): 1727-31.

13. Bielicki JA, Duval X, Gobat N, Goossens H, Koopmans M, Tacconelli E, et al. Monitoring approaches for health-care workers during the COVID-19 pandemic. Lancet Infect Dis 2020; 3099(20): 1-7.

14. Wang D, Hu B, Zhu F, Liu X ZJ. Clinical characteristics of 138 hospitalized patients with 2019 novel coronavirus--Infected pneumonia in Wuhan, China. J Am Med Assoc 2020; 323(11): 1061-9.

15. Celebi G, Piskin N, Beklevic AC, Altunay Y, Keles AS, Tuz MA, et al. Specific risk factors for SARS-CoV-2 transmission among health care workers in a university hospital. Am J Infect Control 2020; 48(10): 1225-30.

16. Deepthi R, Masthi NRR, Nirmala CJ, Manjula R, Vinothkumar S. Personal protective equipments (Ppe) prerequisites, rationale and challenges during covid COVID-19 pandemic. Indian J Community Heal 2020; 32(2): 196-205.

17. Ippolito M, Vitale F, Accurso G, lozzo P, Gregoretti C, Giarratano A, et al. Medical masks and respirators for the protection of healthcare workers from SARS-CoV-2 and other viruses. Pulmonol 2020; 26(4): $204-12$.

18. Sommerstein R, Fux CA, Vuichard-Gysin D, Abbas M, Marschall J, Balmelli C, et al. Risk of SARS-CoV-2 transmission by aerosols, the rational use of masks, and protection of healthcare workers from COVID-19. Antimicrob Resist Infect Control 2020; 9(1): 1-8. 